$16^{\text {th }}$ International Conference on

AEROSPACE SCIENCES \& AVIATION TECHNOLOGY,

ASAT - 16 - May 26 - 28, 2015, E-Mail: asat@ mtc.edu.eg

Military Technical College, Kobry Elkobbah, Cairo, Egypt

Tel : +(202) 24025292 - 24036138, Fax: +(202) 22621908

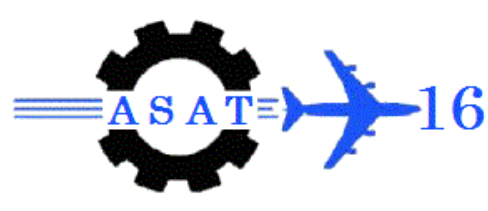

\title{
METALIZED FUEL HYBRID ROCKET MOTOR PARAMETRIC STUDY
}

\author{
Ah. El-S. Makled*
}

\begin{abstract}
The objective of this paper is to study theoretically and experimentally the effects of different design parameters on hybrid rocket motor (HRM). HRM propellant constituents are Polyethylene (PE) with Al powder additive as solid fuel and gaseous oxygen (GO2) as oxidizer. The study has been extended to cover the important phenomena such as throttling operation, exhaust flame (plume) and the results are given in the form of tables and graphs for quick and easy analysis.

The effect of several design parameters on system performance under consideration was investigated. These parameters are the fuel grain port-diameter, oxidizer mass flow rate and Al powder additives.

Focusing on the use of $\mathrm{Al}$ powder weight percentage additives to formulate, improve the regression rate and performance as compared to conventional hybrid motor (pure $\mathrm{PE}+\mathrm{GO}_{2}$ ). Regression rate of hybrid fuel grain was enhanced by addition of $\mathrm{Al}$ powder. Adding up to $7.5 \%$ gives the best performance as regression rate increases by $90 \%$ and chamber pressure increases by $40 \%$ compared to basic configuration $(0 \% \mathrm{Al})$.

The present work is to aid the designer to carry out optimization of HRM to increase the combustion efficiency and to better control the operating parameters.
\end{abstract}

\section{KEY WORDS}

Hybrid Rocket Motor, Regression rate, metal powder additive.

\section{1: INTRODUCTION}

Sergei P. Korolev and Mikhail K. Tikhonravov reported the first recorded effort, as a forerunner to the hybrid rocket, within the scope of the Russian GIRD. A flight was made of the GIRD-09 on 17 August 1933. It was approximately $17.5 \mathrm{~cm}$ in diameter by $2.4 \mathrm{~m}$ long, had a thrust of $500 \mathrm{~N}$ for $15 \mathrm{~s}$ and attained an altitude of $1500 \mathrm{~m}[1,2]$.

Over a 40 years span from 1970 to 2011, the technology of hybrid propulsion motors (HPM) advanced rapidly by French [3], German [4,5], Swedish [6], Israel [7,8,9], India [10,11], United States [12,13,14] and recently England activities [15,16,17].

The four types of chemical propulsion systems; including liquid, solid, hybrid-propellant propulsion systems and ramjet, they are shown in Figure (1).

The third type is hybrid propulsion, which employs propellant ingredients separated both physically and by phase. Solid fuel ramjets are similar to hybrids, but the oxidizer is not stored onboard. Table (1) gives the relative performance comparison of the abovementioned chemical rocket systems.

Until now, regression rates of conventional solid fuels have typically been an order of magnitude lower than approximately $1 / 3$ time of that of solid propellants. Hence, a relatively large fuel-surface area is required to produce a desired thrust level [18].

* Ph.D., Egyptian Armed forces 


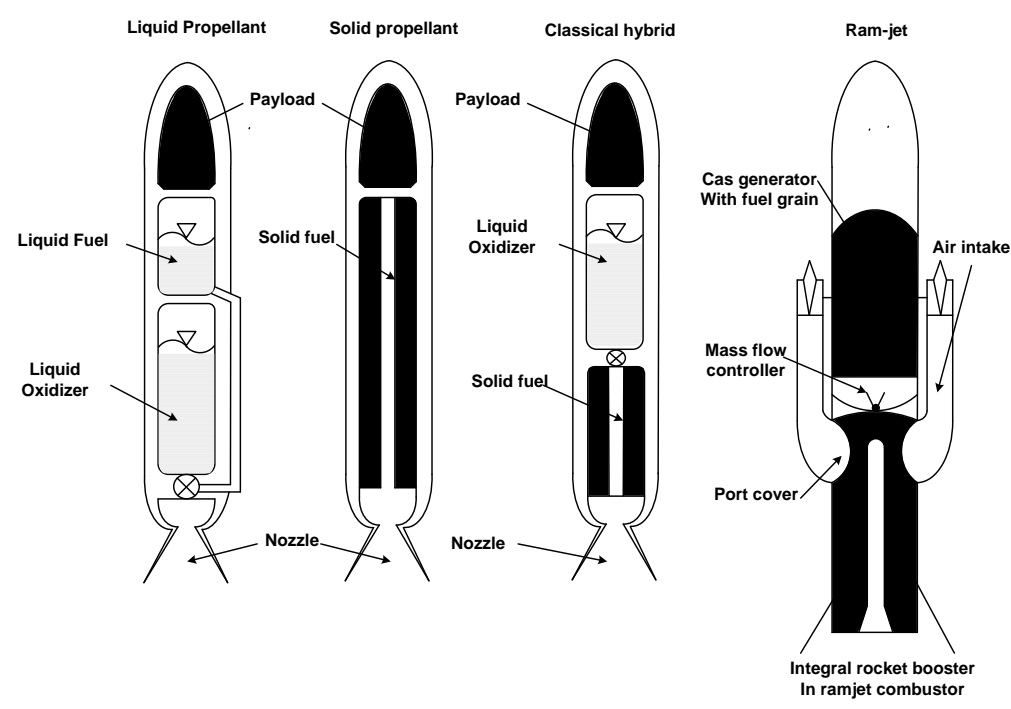

Fig. (1) Types of Chemical Propulsions Systems

Table (1) Chemical Propulsion Systems Characteristics and Performances [18,19]

\begin{tabular}{l|c|c|c|c}
\hline \multicolumn{1}{c|}{ Properties } & Liquid Engine & Solid Motor & Hybrid Engine & Ram-Jet Engine \\
\hline $\mathrm{I}_{\text {sp }}(\mathrm{S})$ & $140-480$ & $260-300$ & $290-380$ & 1200 \\
\hline $\begin{array}{l}\text { Propellant density } \\
\mathrm{kg} / \mathrm{m} 3)\end{array}$ & $850-1150$ & About 1900 & About 900 & 1200 \\
\hline $\begin{array}{l}\text { Regression rate } \\
\text { range }\end{array}$ & ---------- & High \& wide range & Limited (1/3 SPRM) & $\begin{array}{c}\text { Between solid\& } \\
\text { hybrid }\end{array}$ \\
\hline Safety & Approximately safe & Easy to explode & More safe & $\begin{array}{c}\text { SRJ (very safe) LRJ } \\
\text { (safe) }\end{array}$ \\
\hline Simplicity & Bi-prop. complicated & Very simple & $\begin{array}{c}\text { Between solid \& } \\
\text { liquid }\end{array}$ & $\begin{array}{c}\text { Between solid\& } \\
\text { hybrid }\end{array}$ \\
\hline Reliability & Acceptable & Higher & High & High \\
\hline Thrust control & Excellent & Difficult to apply & Fair & $\begin{array}{c}\text { SRJ (fair) } \\
\text { LRJ(excellent) }\end{array}$ \\
\hline Nozzle erosion & Very low & Low & High & Low \\
\hline On-off operation & Excellent & None & Fair & $\begin{array}{c}\text { SRJ (difficult) LRJ } \\
\text { (fair) }\end{array}$ \\
\hline Sliver & $<1 \%$ & $<<2 \%$ & About 6\% & $<1 \%$ \\
\hline Comb. efficiency & About 99\% & About 97\% & About 90\% & About 90\% \\
\hline $\begin{array}{l}\text { Temp. } \\
\text { independency }\end{array}$ & Acceptable & Highly sensitive & Very low sensitive & $\begin{array}{c}\text { Between solid\& } \\
\text { hybrid }\end{array}$ \\
\hline Grain cracks effect & None & High & Low & $\begin{array}{c}\text { Between solid\& } \\
\text { hybrid }\end{array}$ \\
\hline Stable combustion & more stable & $\begin{array}{c}\text { Related to grain } \\
\text { shape }\end{array}$ & Acceptable & Acceptable \\
\hline \hline
\end{tabular}

Due to the mechanism of the hybrid propellant combustion, low combustion efficiency $(\approx 90 \%)$ results from the poor mixing between oxidizer and fuel in the boundary layer over the fuel grain surface when compared to solid rocket system $(\approx 97 \%)$.

Compared to the lower combustion efficiency and solid-fuel regression rates, the hybrid rocket propulsion systems have many major advantages over conventional solid- and liquid-propellant rockets, especially in view of safely, higher density impulse, production costs, minimized environmental impact, on/off operational capability, thrust modulation, and greater controllability. Regarding these advantages, it is of great interest to improve solid-fuel technology as well as to explore new advanced energetic fuel ingredients that can be constituents of potential generation of solid fuels. 
Due to the mechanism of the propellant combustion, the regression behavior of a hybrid engine grain differs considerably from that of a solid rocket propellant. Table (2) presents a comparison of the regression behaviors of solid and hybrid rocket motors.

Table 2 Regression behavior of solid and hybrid rocket motors

\begin{tabular}{l||l||l}
\hline \hline & \multicolumn{1}{|c}{ Solid rocket motor } & \multicolumn{1}{c}{ Hybrid rocket motor } \\
\hline $\begin{array}{l}\text { Dominating combustion } \\
\text { mechanism. }\end{array}$ & - Chemical kinetics. & - Heat transfer. \\
\hline $\begin{array}{l}\text { Main parameter governing } \\
\text { regression. }\end{array}$ & - Combustion chamber pressure. & - Oxidizer mass flux. \\
\hline $\begin{array}{l}\text { Main parameters } \\
\text { governing operating point. }\end{array}$ & $\begin{array}{l}\text { - Clamping (ratio of burning area to port } \\
\text { area). }\end{array}$ & $\begin{array}{l}\text { - Oxidizer mass flow rate. } \\
\text { - Geometry of solid fuel grain. }\end{array}$ \\
$\begin{array}{l}\text { Other parameters } \\
\text { influencing the regression } \\
\text { rate. }\end{array}$ & $\begin{array}{l}\text { - Combustion temperature. } \\
\text { - Particle size of oxidizer. }\end{array}$ & - Composition of solid fuel grain. \\
& $\begin{array}{l}\text { - Gas velial grain temperature. } \\
\text { - Propellant configuration. }\end{array}$ & - Melting point. \\
\hline \hline
\end{tabular}

\section{2: OBJECTIVES AND PREVIOUS WORK}

The main target of the present article is to make a comprehensive theoretical and experimental analysis on the effect of design parameters and operating phenomena of the HRM. A small scale HRM has been designed, manufactured and tested, with different initial port diameter of fuel grain $(5,20$ and $28 \mathrm{~mm})$ and different $\mathrm{Al}$ powder percent $(2.5,5.0,7.5,10.0,12.5$, and $15.0 \%)$. The used propellant was PE in the form of a tubular grain as fuel and gas oxygen as oxidizer [20].

The Hybrid propellant selected as a combination of PE, GO2 and Al powder, PE as solid fuel, its good machinability, low cost, acceptable performance, availability, and safe combustion products, GO2 as oxidizer based on quality of handling, storability, transportability, ignition and toxicity. Finally; choice Al powder as energetic material is based on its thermal properties, ease of processing, and relatively low cost.

The experiments took place for chamber pressure up to 15 bar, firing duration about $5 \mathrm{sec}$, fuel grain length about $75 \mathrm{~mm}$, oxidizer mass flow rate up to $14 \mathrm{gm} / \mathrm{s}$.

Ignition by hot air proved to be a very attractive ignition method, for its higher safety, higher reliability and acceptable delay time (less than $1.7 \mathrm{~s}$.).

The re-start operation was demonstrated several times and can be carried out more easily with hot air ignition method.

A mathematical model has been implemented to solve for the regression rate, chamber pressure-time history and other key performance parameters.

The program was validated through the comparison of predicted and measured performance parameters for a small-scale hybrid test motor.

Comprehensive theoretical and experimental investigations on parameters that affect the performance of hybrid motor have been carried out. The effects of mass flux, geometry of the fuel grain and post combustion chamber on performance have been studied. The comparison between test data and computational results show good agreement [20].

\section{3: DESIGN PARAMETERS THEORETICAL STUDY}




\section{1: Effect of the Fuel Grain Port Geometry}

Since the regression surface $A_{b u}$, and the cross section area $A_{p o}$ are both dependent on the active channel radius, the fuel mass flow rate $\dot{\mathrm{m}}_{\mathrm{fu}}$ will generally change as burning progresses. Both the mixture ratio $\mathrm{O} / \mathrm{F}$ and the combustion chamber pressure $\mathrm{P}_{\mathrm{c}}$ will therefore vary with time.

At steady state operation, the mass conservation implies.

$$
\frac{\mathrm{P}_{\mathrm{c}} \mathrm{A}_{\mathrm{th}}}{\mathrm{C}^{*}}=\dot{\mathrm{m}}_{\mathrm{ox}}+\dot{\mathrm{m}}_{\mathrm{fu}} \quad \text { Eq. (1) }
$$

The simplified formula for fuel mass flow rate is defined as:

$$
\begin{gathered}
\dot{\boldsymbol{m}}_{f u}=a\left(\frac{\dot{\boldsymbol{m}}_{o x}}{A_{p o}}\right)^{n} L_{f u}^{m} A_{b u} \rho_{f u} \\
\frac{\mathrm{P}_{\mathrm{c}} \mathrm{A}_{\mathrm{th}}}{\mathrm{C}^{*}}=\dot{\mathrm{m}}_{\mathrm{ox}}+\mathrm{a}\left(\frac{\dot{\mathrm{m}}_{\mathrm{ox}}}{\mathrm{A}_{\mathrm{po}}}\right)^{\mathrm{n}} \mathrm{L}_{\mathrm{fu}}^{\mathrm{m}} \mathrm{A}_{\mathrm{bu}} \rho_{\mathrm{fu}}
\end{gathered}
$$

where, $A_{\text {th }}$ nozzle throat area, $C^{*}$ characteristic velocity, a regression rate coefficient, $n, m$ regression rate constants, $L_{\mathrm{fu}}$ fuel grain length, $\dot{\mathrm{m}}_{\mathrm{ox}}$ oxidizer mass flow rate and $\rho_{\mathrm{fu}}$ fuel grain density.

At fixed $\dot{\mathrm{m}}_{\mathrm{Ox}}$, the changes in the operating point parameters $\mathrm{P}_{\mathrm{c}}, \mathrm{O} / \mathrm{F}$ and $\mathrm{C}^{*}$ are caused by the term $\mathrm{A}_{\mathrm{bu}} \mathrm{A}_{\mathrm{po}}^{-\mathrm{n}}$, and all other effects must therefore be understood as a consequence of this consideration.

Given a hollow cylinder grain length $\mathrm{L}_{\mathrm{fu}}$, the geometric parameters are.

$$
\left.\begin{array}{l}
\mathrm{A}_{\mathrm{po}}=(\pi / 4) \mathrm{d}_{\mathrm{po}}^{2} \\
\mathrm{~A}_{\mathrm{bu}}=\pi \mathrm{d}_{\mathrm{po}} \mathrm{L}_{\mathrm{fu}}
\end{array}\right\}
$$

Therefore, $\mathrm{A}_{\mathrm{bu}} \mathrm{A}_{\mathrm{po}}^{-\mathrm{n}}=$ constantd $\mathrm{po}^{1-2 \mathrm{n}}$

It follows from this equation that in case of a cylindrical port grain, if no change of the operating point is required, the oxidizer mass flux exponent $\mathrm{n}$ should be equal to 0.5 .

\section{2: Prediction of Port Diameter Variation at Constant Oxidizer Flow Rate}

It is nice to be able to predict the actual port diameters at any given instance of time by a simplified equation. Beginning with the fuel regression rate, $r_{\text {fu }}$ as $[18,19]$ :

$$
\dot{\mathrm{r}}_{\mathrm{fu}}=\mathrm{a} \mathrm{G}_{\mathrm{ox}}^{\mathrm{n}} \mathrm{L}_{\mathrm{fu}}^{\mathrm{m}} \quad \text { Eq. (5) }
$$

Where, $\mathrm{G}_{\mathrm{ox}}$ oxidizer mass flux. The change of port diameter $\mathrm{d}_{\mathrm{po}}$ with operating time $\mathrm{t}_{\mathrm{bu}}$ can be determined as follows.

$$
\dot{\mathrm{r}}_{\mathrm{fu}}=\frac{1}{2} \frac{\mathrm{d}_{\mathrm{d}_{\mathrm{po}}}}{\mathrm{dt}}=\mathrm{a}\left(\frac{4 \dot{\mathrm{m}}_{\mathrm{ox}}}{\pi \mathrm{d}_{\mathrm{po}}^{2}}\right)^{\mathrm{n}} \mathrm{L}_{\mathrm{fu}}^{\mathrm{m}} \quad \text { Eq. (6) }
$$




$$
\begin{aligned}
& \frac{1}{2} \frac{\mathrm{d}_{\mathrm{d}_{\mathrm{po}}}}{\mathrm{dt}}=\mathrm{a}\left(\frac{4 \dot{\mathrm{m}}_{\mathrm{ox}}}{\pi}\right)^{\mathrm{n}} \mathrm{L}_{\mathrm{fu}}^{\mathrm{m}} \mathrm{d}_{\mathrm{po}}^{-2 \mathrm{n}} \quad \text { Eq. (7) } \\
& \int_{\mathrm{po}, \mathrm{i}}^{\mathrm{d}_{\mathrm{po}}} \mathrm{d}_{\mathrm{po}}^{2 \mathrm{n}} \mathrm{d}_{\mathrm{d}_{\mathrm{po}}}=2 \mathrm{a}\left(\frac{4 \dot{\mathrm{m}}_{\mathrm{ox}}}{\pi}\right)^{\mathrm{n}} \mathrm{L}_{\mathrm{fu}}^{\mathrm{m}} \int_{0}^{\mathrm{t}} \mathrm{dt} \text { Eq. (8) }
\end{aligned}
$$

Integration leaves a general expression for the instantaneous diameter of the circular port grain as

$$
\mathrm{d}_{\mathrm{po}}(\mathrm{t})=\left[2 \mathrm{a}(2 \mathrm{n}+1)\left(\frac{4 \dot{\mathrm{m}}_{\mathrm{ox}}}{\pi}\right)^{\mathrm{n}} \mathrm{L}_{\mathrm{fu}}^{\mathrm{m}} \mathrm{t}+\mathrm{d}_{\mathrm{po}, \mathrm{i}}^{(2 \mathrm{n}+1)}\right]^{\frac{1}{2 \mathrm{n}+1}}
$$

\section{3: Effect of the Fuel Grain Length}

Since in the case of HRM, the $\mathrm{P}_{\mathrm{c}}$ and therefore also the thrust go under variations during the combustion period, the current dimensions of the solid fuel grain (SFG) can be determined only in relation to a particular point of time in the operating cycle.

Using initial thrust $F_{i}$, initial mixture ratio $\phi_{\mathrm{I}}$ and specific impulse $\mathrm{I}_{\mathrm{sp}, \mathrm{i}}$, one obtains the initial $\mathrm{m}_{\mathrm{ox}}$ as

$$
\dot{\mathrm{m}}_{\mathrm{ox}}=\frac{\mathrm{F}_{\mathrm{i}}}{\mathrm{I}_{\mathrm{sp}, \mathrm{i}} \mathrm{g}\left(1+1 / \phi_{\mathrm{i}}\right)}
$$

Recalling Eq. $2 \quad \dot{\mathrm{m}}_{\mathrm{fu}}=\mathrm{a}_{\mathrm{fu}}^{\mathrm{m}}\left(\frac{\dot{\mathrm{m}}_{\mathrm{ox}}}{\mathrm{A}_{\mathrm{po}}}\right)^{\mathrm{n}} \mathrm{A}_{\mathrm{bu}} \rho_{\mathrm{fu}}$

The initial geometry parameter can be written as:

$$
A_{b u, i} A_{P o, i}^{-n}=\frac{1}{\phi_{i} \rho_{f u} a L_{f u}^{m}}\left[\frac{F_{i}}{I_{s p, i} g\left(1+\frac{1}{\phi_{i}}\right)}\right]^{1-n}=K_{o} \quad \text { Eq. (11) }
$$

The right hand side of the above equation can be assumed as constant $\mathrm{k}_{\mathrm{o}}$ for any design mission. Since burning surface $A_{b u, i}$ is proportional to the length of the propellant grain, this means the thrust increases as the length of the fuel grain raised to the power $1 /(1-n)$ ( $\left.\mathrm{F} \propto \mathrm{L}_{\mathrm{fu}}^{1 / 1-n}\right)$.

For $n=0.5$ then $\mathrm{F} \propto \mathrm{L}_{\mathrm{fu}}^{2}$, therefore, high thrust requirements leads to long fuel grains. 


\section{4: Prediction of Mixture Ratio Shift}

The SFG charge must be designed in accordance with the particular demands of the required mission. The dimensions of the solid fuel should satisfy minimum shift of $\mathrm{O} / \mathrm{F}$ with operating time while securing maximum hybrid performance.

The main disadvantage of HRM consists in the shifting O/F during the operation; it would be desirable to design a motor that operates at or near the optimum $\mathrm{O} / \mathrm{F}$. This value is absolutely different from the stochiometric mixture ratio $(\mathrm{O} / \mathrm{F})_{\text {sto. }}$.

During the firing operation, the $\mathrm{A}_{\mathrm{po}}$ increases for a fixed $\dot{\mathrm{m}}_{\mathrm{ox}}$, the actual $\mathrm{O} / \mathrm{F}$ will increase during the operation. As a result, a flight motor would be designed to begin combustion at an $\mathrm{O} / \mathrm{F}$ somewhat lower than the optimum value so the efficiency would be increasing over time with a near optimum integrated efficiency achieved.

The initial $\mathrm{O} / \mathrm{F}$ from the required flow rates.

$$
(\mathrm{O} / \mathrm{F})_{\mathrm{i}}=\frac{\dot{\mathrm{m}}_{\mathrm{ox}, \mathrm{i}}}{\dot{\mathrm{m}}_{\mathrm{fu}, \mathrm{i}}}=\frac{\dot{\mathrm{m}}_{\mathrm{ox}, \mathrm{i}}}{\dot{\mathrm{r}}_{\mathrm{fu}, \mathrm{i}} \rho_{\mathrm{fu}} \mathrm{A}_{\mathrm{bu}, \mathrm{i}}} \quad \text { Eq. (12) }
$$

The final $\mathrm{O} / \mathrm{F}$

$$
(\mathrm{O} / \mathrm{F})_{\mathrm{f}}=\frac{\dot{\mathrm{m}}_{\mathrm{ox}, \mathrm{f}}}{\dot{\mathrm{m}}_{\mathrm{fu}, \mathrm{f}}}=\frac{\dot{\mathrm{m}}_{\mathrm{ox}, \mathrm{f}}}{\dot{\mathrm{r}}_{\mathrm{fu}, \mathrm{f}} \rho_{\mathrm{fu}} \mathrm{A}_{\mathrm{bu}, \mathrm{f}}}
$$

The $\dot{\mathrm{m}}_{\mathrm{ox}}$ is assumed constant along system operation, then together with Eq. 12 and Eq. 13, the $\mathrm{O} / \mathrm{F}$ shift can be described as function of change of fuel grain port diameter as:

$$
\frac{(O / F)_{f}}{(O / F)_{i}}=\left[\frac{d_{p o, i}}{d_{p o, f}}\right]^{2 n-1}
$$

The above relation is valid only for tubular grain shape. It can be seen that for $n>0.5$, the port area increases during operation and the $\mathrm{O} / \mathrm{F}$ increases. Notice that at $\mathrm{n}=0.5, \mathrm{O} / \mathrm{F}$ does not vary with change of fuel grain port diameter or operation time.

\section{4: EXPERIMENTAL STUDY}

\section{1: Effect of Fuel Grain Port Diameter}

A series of experimental test motor has been fired for different initial port diameters $(5,20$ and $28 \mathrm{~mm}$ ) with constant fuel grain length $(70$ to $80 \mathrm{~mm})$ for burning durations around $5 \mathrm{sec}$. and $\mathrm{Al}$ powder weight percentage additives $(2.5,5.0,7.5,10.0,12.5$, and 15.0\%). As shown in Figure (2), observations of the SFG active channels before and after a burning reveal that, the remaining fuel grain port surface is relatively smooth. Combustion of PE material produces carbon particles in the flame zone that can spread out black carbon to the surface along combustion port. Slight inflating toward the GO2 injection head is also observed, in particular with small initial port $5 \mathrm{~mm}$.

The reasons of the ablation in the immediate vicinity of the injection head may be explained by the oxidizer jet injection, which actually strikes the fuel grain, and then the solid material will be deeply eroded at these points of the combustion channel.

The small fuel grain port makes many problems especially after firing with heat exchanger ignition method. The molten PE at the end face of fuel grain moves back to oxidizer injection head and blocks the injectors, Figure (3). These problems could be solved by placing a gasket from insulation material (ASBESTOS) between fuel grain end face and injection head. 
On other hand, for fuel grain with small port, neither pyrotechnic charge, nor heat wire, nor fuse wire was able to successfully ignite the fuel grain. High oxygen mass flux invokes coughing ignition spot (initiation point) before built up. Fortunately, hot air ignition method gives excellent ignition results with the small port area.

More smooth fuel grain surface and less soot have been observed when using Al additive. In conclusion, the initial fuel grain port diameter (active channel port) is shown to be one of the critical parameters encountered in HRM design.

Figures (4) and (5) illustrate the effect of initial port diameter (5 $\mathrm{mm}$ to $28 \mathrm{~mm}$ ) on HRM regression rate and average chamber pressure at nearly constant $\mathrm{m}_{\mathrm{ox}}$, and $\mathrm{L}_{\mathrm{fu}}$ for a variety of $\mathrm{Al}$ powder additives (2.5 up to $15 \%$ by weight).
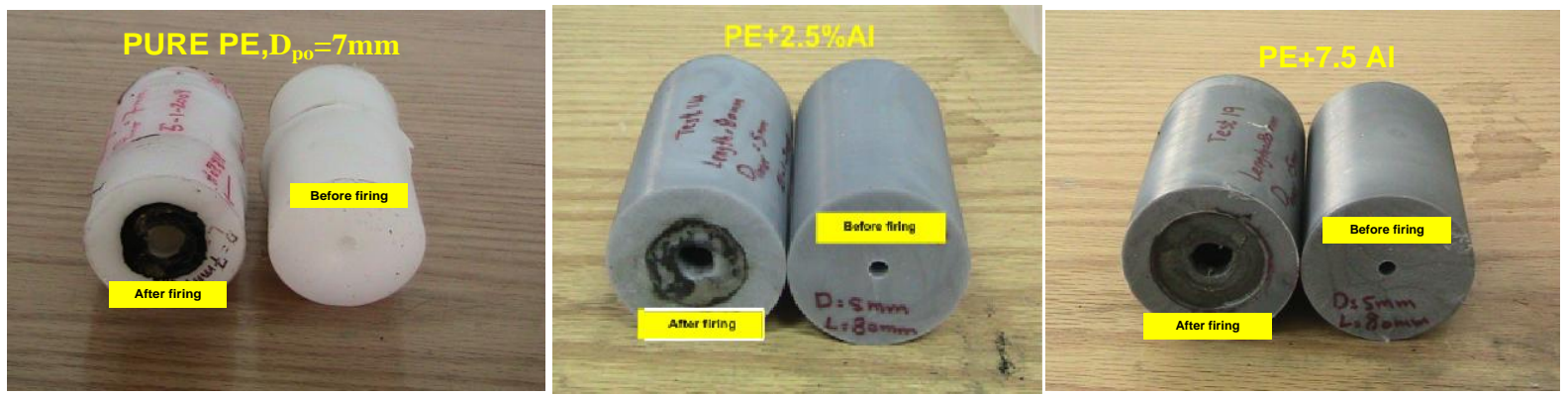

Fig. (2) PE Active Channel Port Before and After Firing
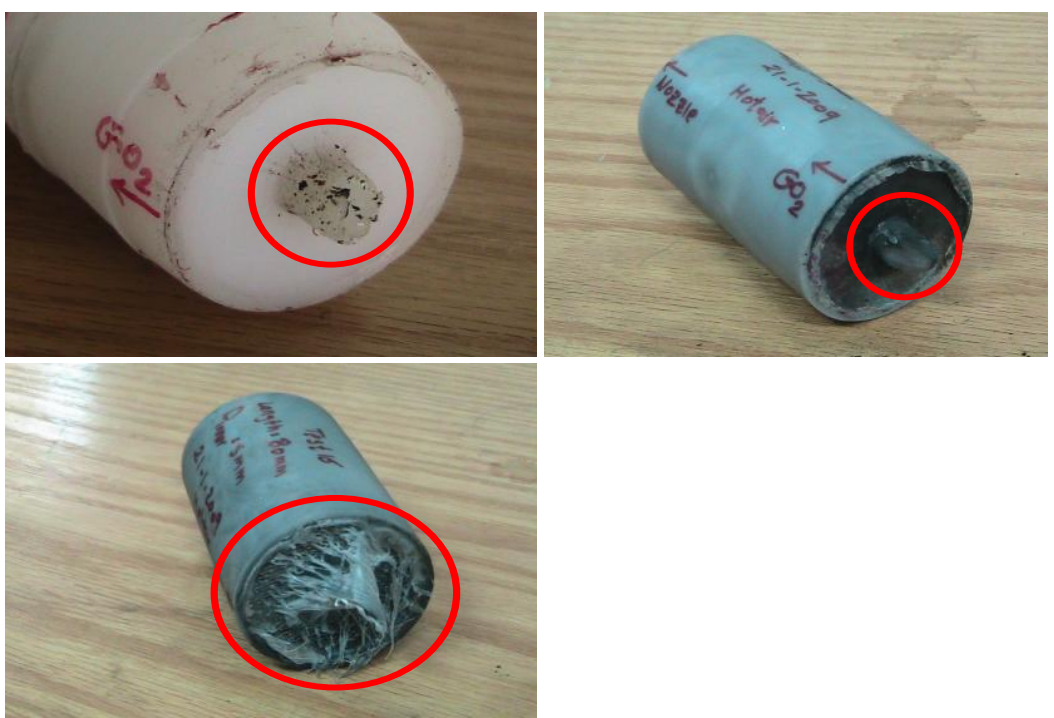

Fig. (3) Molten Fuel Material Moves Back to Block Injectors

As seen from Figure (4), the average regression rate decreases with the increase of port diameter. This increase is more significant at lower initial port diameters.

Considering the port diameters from $5 . \mathrm{mm}$ to less than $20 \mathrm{~mm}$, it could be seen that the average regression rate increases with increasing the percentage of $\mathrm{Al}$ powder up to $7.5 \%$. With the percentage of $\mathrm{Al}$ powder higher than $7.5 \%$, the phenomenon is reversed, i.e., the average regression rate decreases with the increase of $\mathrm{Al}$ powder up to $15 \%$. This effect is insignificant at $20 \mathrm{~mm}$ initial diameter up to $28 \mathrm{~mm}$.

This may be explained by the balance between the effects of Al percentage and the port diameter on the degree of erosion rate of the fuel material. 


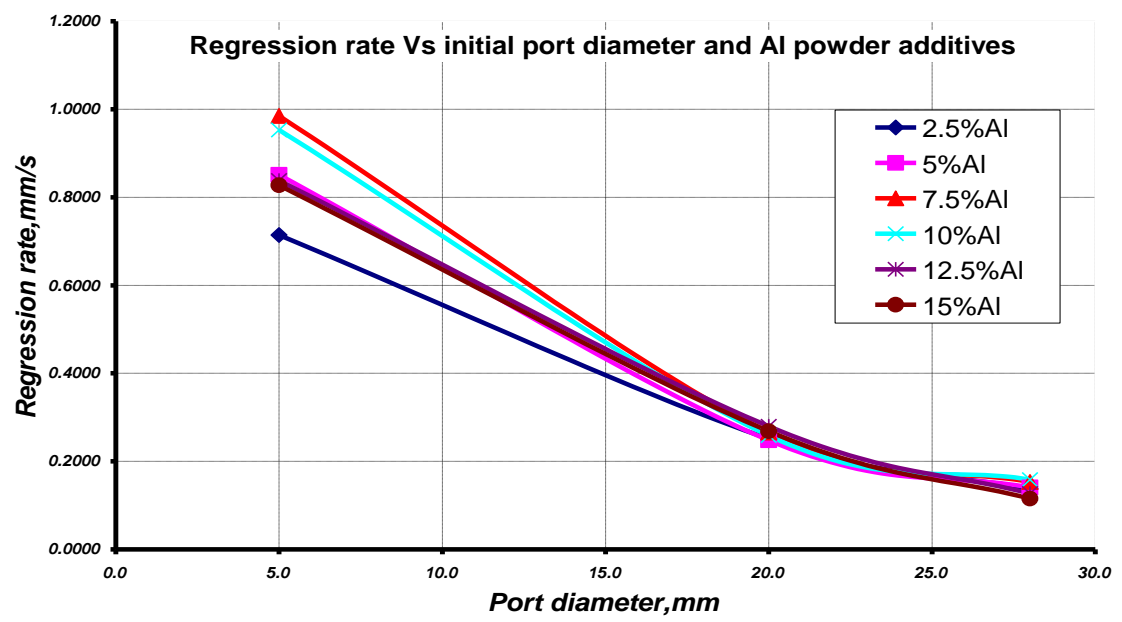

Fig. (4) Regression Rate Versus Initial Port Diameter and Al Powder Additives

Figure (5) describes the variation of average chamber pressure with fuel grain initial port diameter at different $\mathrm{Al}$ powder additives.

For initial port diameter $5 \mathrm{~mm}$ up to $20 \mathrm{~mm}$, the average chamber pressure slightly decreases with the increase of port diameter. That effect is steeper for port diameters from $20 \mathrm{~mm}$ up to $28 \mathrm{~mm}$.

For $\mathrm{Al}$ powder from $2.5 \%$ up to $7.5 \%$, the average chamber pressure increases with the increase of $\mathrm{Al}$ percentage. For $\mathrm{Al}$ powder more than $7.5 \%$ up to $15 \%$ the behavior is reversed, i.e., as the $\mathrm{Al} \%$ increases the average chamber pressure decreases.

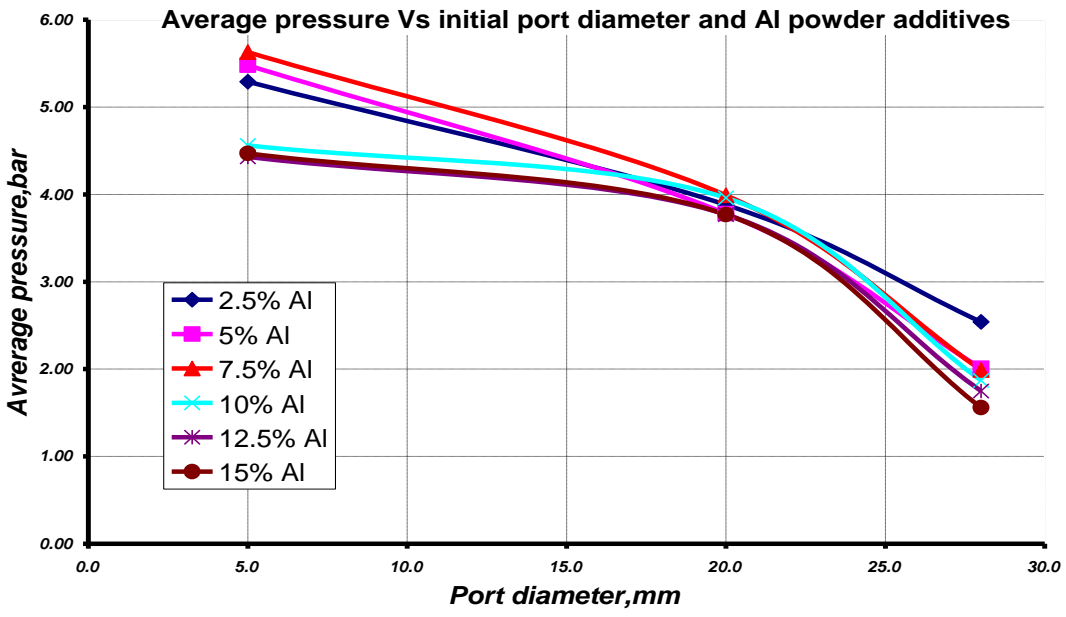

Fig. (5) Average Pressure Versus Initial Port Diameter and Al Powder Additives

Finally, it could be concluded that the addition of $7.5 \% \mathrm{Al}$ powder gives the highest performance for the case under study. Comparing this case $(7.5 \% \mathrm{Al})$ with the base line configuration $(0 \% \mathrm{Al})$ a regression rate increase of $90 \%$ and chamber pressure increase of $40 \%$ were reached. This has an excellent impact on the overall performance of the HRM with $\mathrm{Al}$ additive. It is claimed that it is always possible to deduce the proper Al percentage that leads to the best performance for a given case under study.

For smaller values of initial port diameter of fuel grain, the chamber pressure and regression rate are generally increased.

To compensate the effect of port diameter variation during firing, three solutions are proposed:

- By a special design of fuel grain configuration.

- Using layers of fuel grain with different materials.

- By controlling the oxidizer mass flow rate during the burning time, such that a nearly constant regression rate would be obtained. 


\section{2: Effect of Oxidizer Mass Flow Rate}

The effect of changing the oxidizer mass flow rates on the HRM parameters is summarized in Table (4). The motor dimensions and the propellant characteristics are kept unchanged. It could be shown that, for the range of oxidizer mass flow in these tests, the combustion efficiency decreases as the oxidizer mass flow rate increases. It is believed that, for each specified case, it is possible to find the oxidizer flow rate for which the efficiency would be maximized.

Table (4) shows also that the hybrid motor combustion chamber pressure is strongly dependent on the oxidizer mass flow rate. Figure (6) shows the combustion chamber pressure for two different oxidizer mass flow rates.

Table (3)Hybrid Parameters at Different Oxidizer Mass Flow Rates

\begin{tabular}{|c|c|c|c|}
\hline \multirow[b]{2}{*}{ Parameters } & \multicolumn{3}{|c|}{$\mathrm{D}_{\mathrm{po}}=5 \mathrm{~mm}, \mathrm{~L}_{\mathrm{fu}}=80 \mathrm{~mm}$, duration $\approx 5 \mathrm{sec}$} \\
\hline & $\begin{array}{l}(\text { Test } 3 / 5 *) 5 \% \mathrm{Al}, \\
\dot{\mathrm{m}}_{\mathrm{ox}}=8.7 \mathrm{gm} / \mathrm{s}\end{array}$ & $\begin{array}{l}\text { (Test } 1 / 5 *) 5 \% \mathrm{Al} \\
\dot{\mathrm{m}}_{\mathrm{ox}}=9.1 \mathrm{gm} / \mathrm{s}\end{array}$ & $\begin{array}{l}\left(\text { Test } 2 / 5^{*}\right) 5 \% \mathrm{Al} \\
\dot{\mathrm{m}}_{\mathrm{ox}}=9.2 \mathrm{gm} / \mathrm{s}\end{array}$ \\
\hline Regression rate, $(\mathrm{mm} / \mathrm{s})$ & 1.0809 & 0.8509 & 0.8878 \\
\hline Chamber pressure, (bar) & 5.93 & 5.48 & 5.44 \\
\hline Mixture ratio, (-) & 3.46 & 4.57 & 4.08 \\
\hline Experimental $\mathrm{C}^{*}(\mathrm{~m} / \mathrm{s})$ & 1495.2 & 1396.9 & 1342.5 \\
\hline Theoretical C* $(\mathrm{m} / \mathrm{s})$ & 1651.4 & 1588.7 & 1620.6 \\
\hline Combustion efficiency, (\%) & 90.5 & 87.9 & 82.8 \\
\hline
\end{tabular}

* Details of tests are given in reference [20]

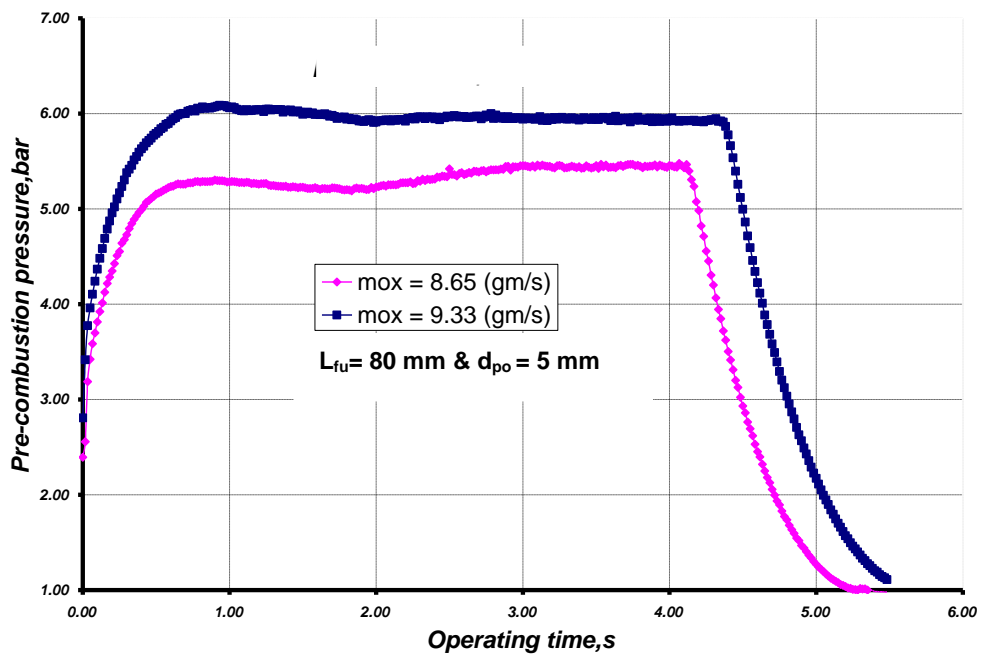

Fig. (6) Combustion Chamber Pressure versus Firing Time

\section{3: Effect of Al Powder Additives}

The low performance resulting from the poor mixing between oxidizer and fuel in the turbulent boundary layer over the fuel grain surface was recognized in many classical HRM. To overcome this drawback of the conventional HRM, energetic additives were proposed to be used with fuel grain to enhance performance in particular the regression rate and chamber pressure.

Table (4) and Figure (7) describe the effect of Al\% on the HRM performance, especially chamber pressure, regression rate and combustion efficiency.

Each of the regression rate and chamber pressure increases with the increase of additive $\mathrm{Al} \%$ to fuel grain material up to $7.5 \%$. With $\mathrm{Al} \%$ higher than $7.5 \%$ poorer combustion efficiency is encountered.

Analysis of experimental results may lead to the following remarks:

1) Ignition delay time decreases with increasing of $\mathrm{Al} \%$.

2) Each of the regression rate, the chamber temperature and the chamber pressure increases as $\mathrm{Al} \%$ increases. 
3) The combustion efficiency reaches highest value at $2.5 \% \mathrm{Al} \%$.

4) No significant variation on the regression rate or performance is observed when using Al powder more $7.5 \%$.

The variation of average experimental regression rates with oxidizer mass flux at different. $\mathrm{Al} \%$ additives is shown in Figure (8). The regression rate increases more sharply at lower oxidizer mass flux, but the increase gets more flat at higher oxidizer mass flux.

Table (4) Effects of Al Powder Additives

\begin{tabular}{l|l|l||l|l}
\hline \hline Parameter & $\begin{array}{l}\text { Test 1/3* } \\
(\text { Base line }) \\
(\text { pure PE) }\end{array}$ & $\begin{array}{l}\text { Test 2/4* } \\
(2.5 \% \mathrm{Al})\end{array}$ & $\begin{array}{l}\text { Test 2/5* } \\
(5 \% \mathrm{Al})\end{array}$ & $\begin{array}{l}\text { Test 2/6* } \\
(7.5 \% \mathrm{Al})\end{array}$ \\
\hline \hline Chamber pressure(bar) & 3.92 & 5.29 & 5.44 & 5.63 \\
\hline Average mixing ratio(-) & 6.91 & 6.62 & 9.2 & 8.9 \\
\hline Regression rate(mm/s). & 0.5146 & 0.7143 & 0.8878 & 0.9848 \\
\hline Experimental C* (m/s). & 913.5 & 1397.3 & 1342.5 & 1368.5 \\
\hline Theoretical C* $(\mathrm{m} / \mathrm{s})$. & 1479.8 & 1490.8 & 1620.6 & 1676.7 \\
\hline Combustion efficiency $(\%)$. & 61.7 & 93.7 & 82.8 & 81.6 \\
\hline \hline
\end{tabular}

* Details of tests are given in Reference [20]

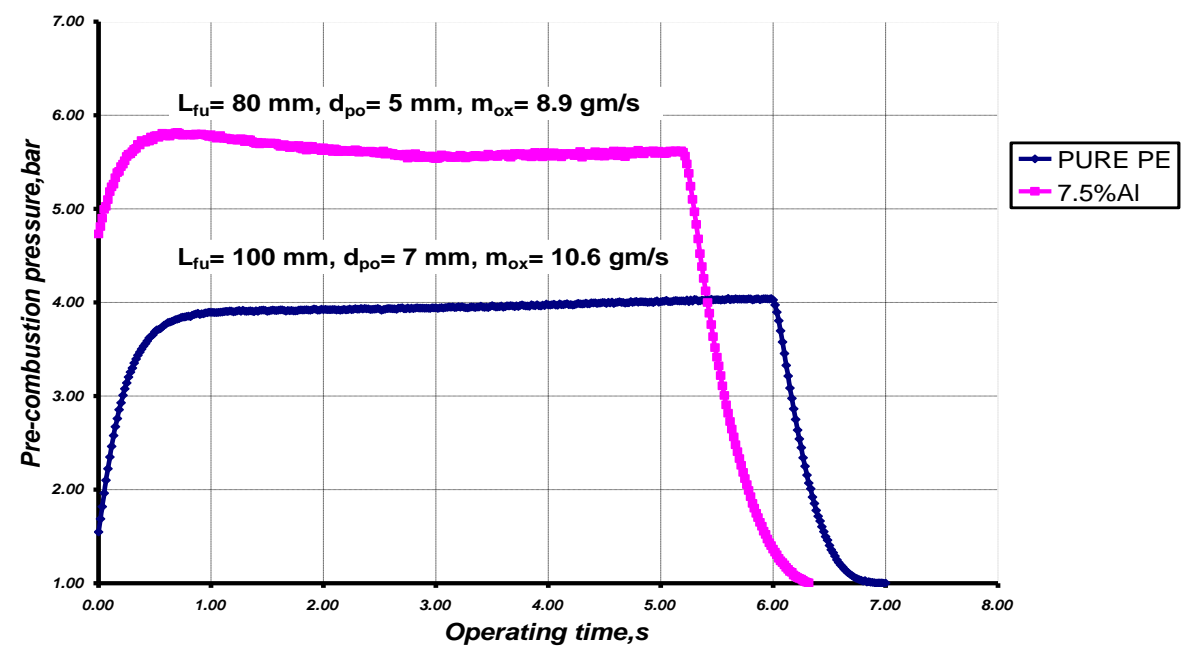

Fig. (7) Chamber Pressure Versus Time, with and Without Al Powder 


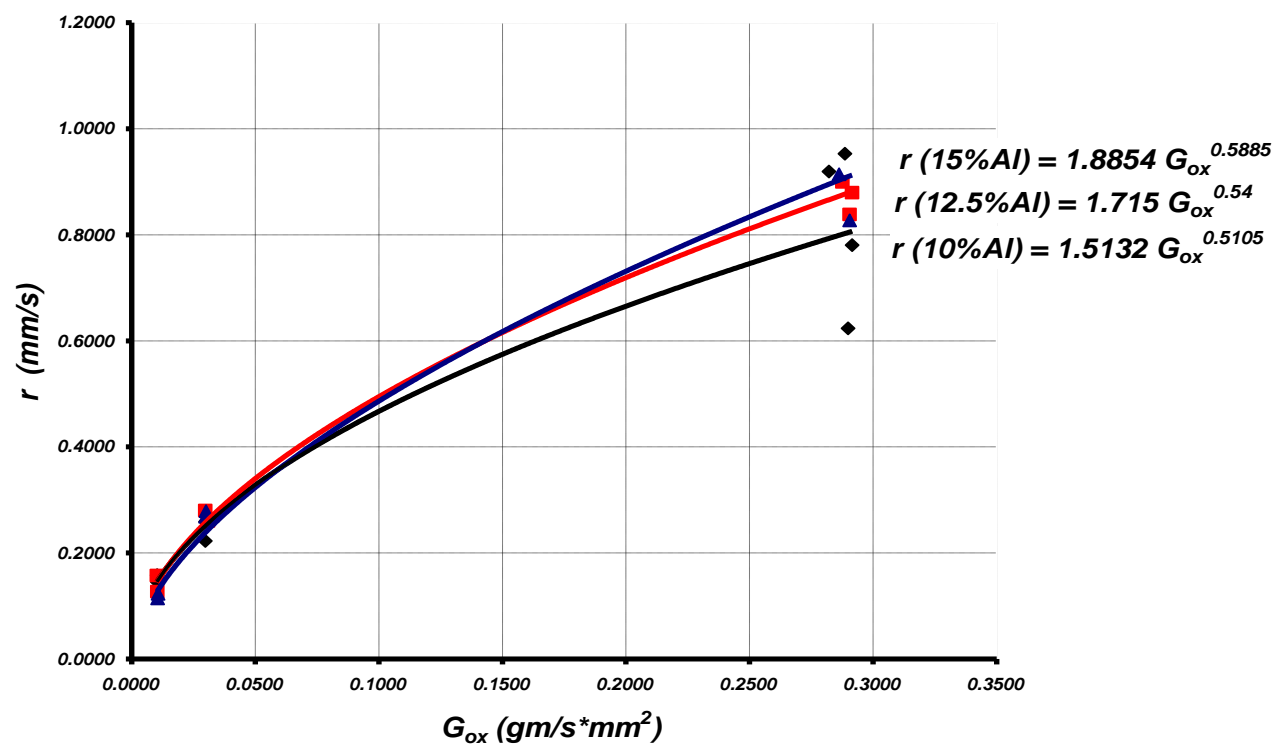

Fig. (8) Regression Rates with Various Oxidizer Mass Fluxes at Different A1\%

\subsection{1: Formulation of the Regression Rate}

Making use of the experimental data now available, it is worthy to express the regression rate as function of mass flux with consideration of $\mathrm{Al} \%$ addition. The data are plotted in Figure (9) and two representative curves that describe the trends of variation are traced. These trends are mathematically expressed to reflect the empirical regression rate as follows:

For $\mathrm{Al} \leq 7.5 \%$

$$
\dot{\mathrm{r}}=2.0357 \mathrm{G}_{\circ \mathrm{x}}^{0.5688}(\mathrm{~mm}, \mathrm{gm}, \mathrm{s})
$$

For $\mathrm{Al}>7.5 \%$

$$
\dot{\mathrm{r}}=1.6657 \mathrm{G}_{\mathrm{ox}}^{0.5417}(\mathrm{~mm}, \mathrm{gm}, \mathrm{s})
$$

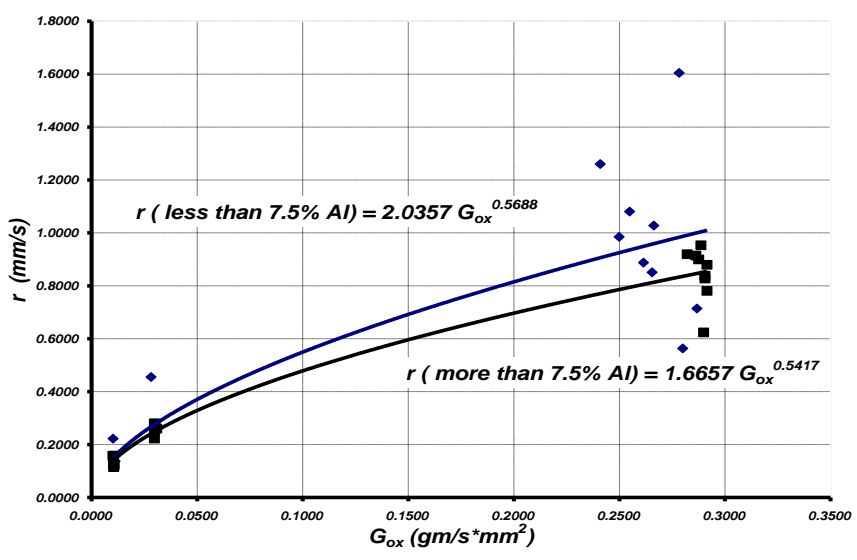

Fig. (9) Al Powder \% Effect Regime on the Regression Rate

\subsection{2: Effect of Al Particles on Nozzle Throat}

One of the problems encountered is that a quite large amount of solid aluminum particles is formed during the expansion (exhaust gases). These solid particles cause erosion of nozzle throat, especially at high oxidizer mass flux or long duration. Enlargement of the nozzle throat dimensions is the direct consequence of the effect of Al particles, Figure (10). The thrust magnitude will be changed accordingly, but a pre-knowledge of such behavior would help compensate this effect. 


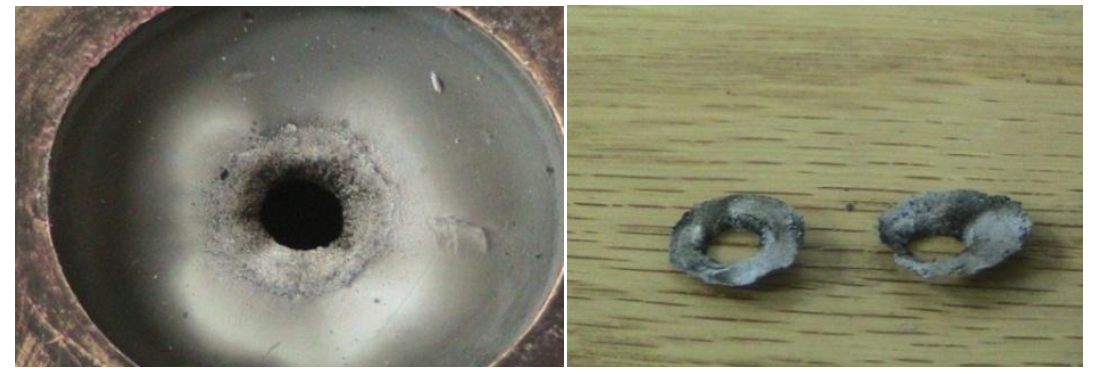

Fig.(10) Nozzle Throat as Affected by Al Particles

\section{5: PHENOMENA STUDY}

\section{1: Throttling Operation}

Thrust modulation could be achieved either through a change of the throat area or the combustion pressure. Nozzle throat variation is extremely difficult during operation. So, thrust modulation through pressure variation can be used. Pressure change may be realized by controlling the main flow rate of oxidizer injection.

The thrust of HRM could be regulated and terminated using a single controlling valve at oxidizer feeding line (solenoid valve normally closed).Increasing the oxidizer mass flow results in an increasing mixture ratio $\mathrm{O} / \mathrm{F}$ value and a part of propellant remains un-reacted in the combustion chamber. Another important problem associated with throttling is the increasing instability of combustion, due to change in feeding system characteristics.

Figure (11) shows a record of throttling in the supply line of oxidizer gas. The variation of pressure and temperature is represented by two pulses that describe the transition caused by closing and opening the valve in the gas line.

From the figure, it can be seen that values of chamber pressures are varied depending on the variations in the oxidizer flow rate. A throttling capability (maximum to minimum chamber pressure) of (10.7/4.1) could be achieved by the decreasing oxidizer flow rate by $14.4 \%(10.4$ to $8.9 \mathrm{gm} / \mathrm{s})$.

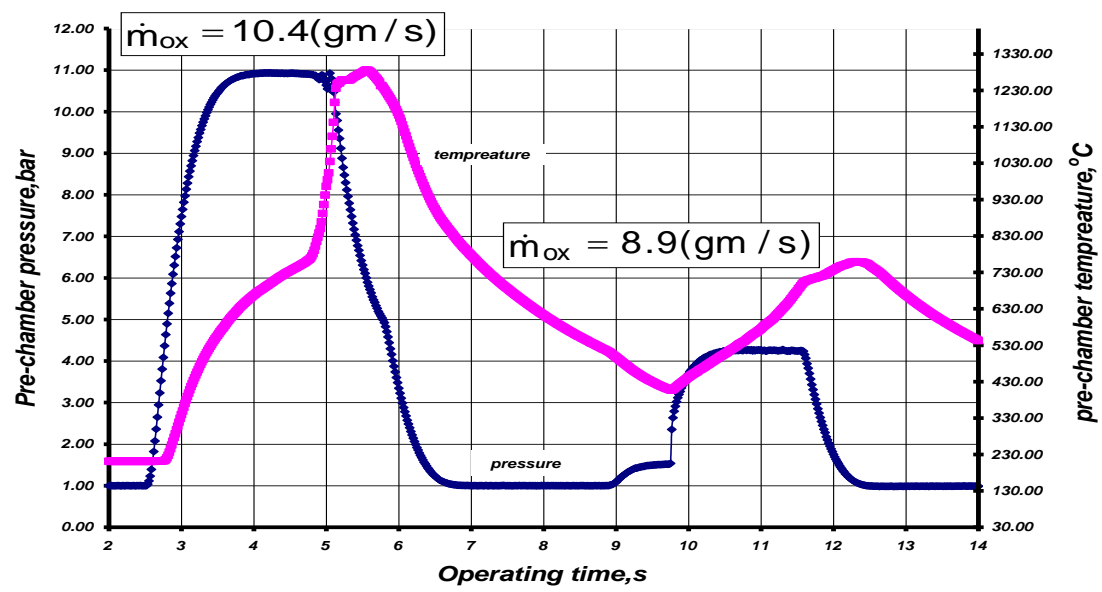

Fig. (11) Throttling Operation of Hybrid Rocket Motor

\section{2: Exhaust Flame (Plume) Properties}

The visualization results of practical HRM are obtained for PE with Al powder as fuel plus gaseous oxygen as oxidizer. Figure (12) shows a direct photograph during steady combustion at $3 \mathrm{sec}$ after ignition, the plume, which is constructed under an atmospheric pressure, is formed at the immediate vicinity of exit nozzle. Observing the plume gives evidence that combustion is still occurring along the combustion gases after leaving the nozzle. The exhaust gases contains high amount of unburned fuel and several particles of Al powder which react with atmospheric oxygen. This is demonstrated by the red color observed around the plume, which means lower combustion efficiency of HRM. 
The exhaust plume configuration changes according to nozzle shape, Figure (13) Table (5) describes the distribution of exhaust gas temperature along the plume length for different $\mathrm{Al} \%$ additives. These results were calculated using thermo chemical calculations [21].

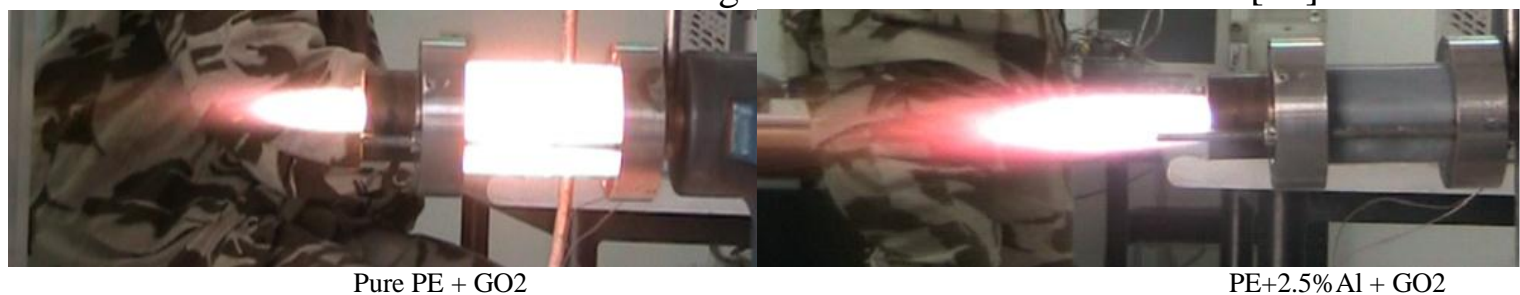

Pure PE + GO2

$\mathrm{PE}+2.5 \% \mathrm{Al}+\mathrm{GO} 2$

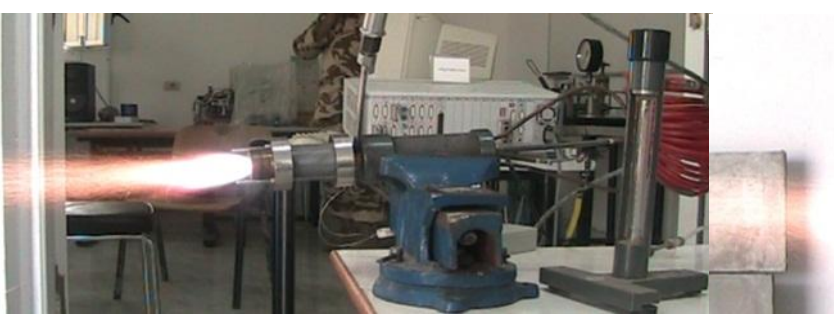

$\mathrm{PE}+7.5 \% \mathrm{Al}+\mathrm{GO} 2$

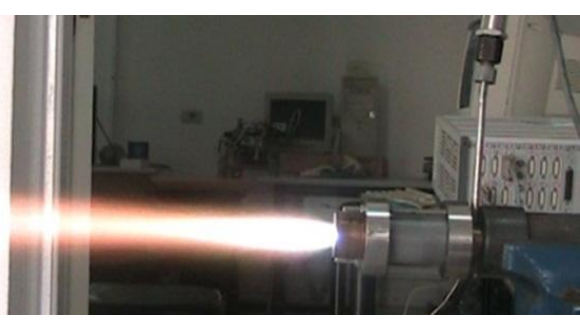

$\mathrm{PE}+15 \% \mathrm{Al}+\mathrm{GO} 2$

Fig. (12) Exhaust Plume Jet during Combustion

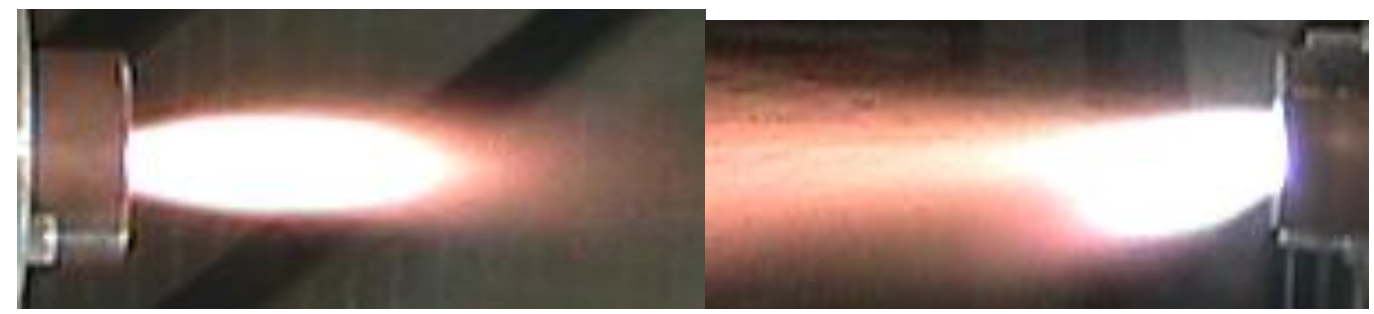

$\mathrm{d}_{\mathrm{th}}=3 \mathrm{~mm}$ with area ratio $=10, \mathrm{P}_{\mathrm{C}}=2.01 \mathrm{bar} \quad \mathrm{d}_{\mathrm{th}}=5 \mathrm{~mm}$ with area ratio $=15, \mathrm{P}_{\mathrm{C}}=4.47 \mathrm{bar}$

Fig. (13) Exhaust Flame (Plume) Shape for Different Nozzle Shape

Table (4) Theoretical Exhaust Flame Plume Temperature (K)

forPE, AlAdditives with $\mathrm{GO}_{2}$ at $\mathrm{P}_{\mathrm{c}}=7 \mathrm{bar}, \mathrm{O} / \mathrm{F}=2$

\begin{tabular}{|c|c|c|c|c|c|c|c|}
\hline \multirow{2}{*}{$\begin{array}{l}\text { Plume } \\
\text { length }\end{array}$} & \multicolumn{7}{|c|}{ Exhaust flame plume temperature (k) } \\
\hline & pure & $2.5 \% \mathrm{Al}$ & $5 \% \mathrm{Al}$ & $7.5 \% \mathrm{Al}$ & $10 \% \mathrm{Al}$ & $12.5 \% \mathrm{Al}$ & $15 \% \mathrm{Al}$ \\
\hline$\varepsilon=1$ & 2999.85 & 3053.93 & 3105.80 & 3152.59 & 3195.10 & 3234.80 & 3270.09 \\
\hline $\begin{array}{l}\varepsilon=\text { adapted } \\
\text { nozzle }\end{array}$ & 2497.64 & 2581.93 & 2658.90 & 2728.39 & 2790.43 & 2845.32 & 2893.89 \\
\hline$\varepsilon=10$ & 1634.47 & 1750.17 & 1872.44 & 1998.87 & 2124.96 & 2244.75 & 2326.99 \\
\hline$\varepsilon=15$ & 1470.64 & 1578.75 & 1695.01 & 1819.04 & 1948.25 & 2077.84 & 2200.40 \\
\hline$\varepsilon=20$ & 1365.92 & 1468.04 & 1578.88 & 1698.63 & 1826.19 & 1958.29 & 2088.67 \\
\hline
\end{tabular}

\section{6:. CONCLUSION}

A small scale HRM has been designed, manufactured and tested by using different initial port diameter and length of PE fuel, different metalized Al powder percent as fuel additives and $\mathrm{GO} 2$ as oxidizer.

The first phase of the study is devoted to study the effect of design parameters theoretically. Results can be summarized as follows:

- At fixed oxidizer mass flow rate, the changes in the operating point parameters $\mathrm{P}_{c}, \mathrm{O} / \mathrm{F}$ and $\mathrm{C}^{*}$ are caused by the term $\mathrm{A}_{\mathrm{bu}} \mathrm{A}_{\mathrm{po}}^{-\mathrm{n}}$, and for tubular fuel grain, $A_{b u} A_{p o}^{-n}=$ constantd $_{\text {po }}^{1-2 n}$, if no change of the operating point is required, the oxidizer mass flow flux exponent $\mathrm{n}$ should be is equal to 0.5 . 
- It is nice to be able to predict the actual fuel port diameters and $\mathrm{O} / \mathrm{F}$ shift at any given instance of firing time.

- For regression rate, mass flux constant $n>0.5$ the port area increases during operation and the $\mathrm{O} / \mathrm{F}$ increases during firing. Notice that at $\mathrm{n}=0.5, \mathrm{O} / \mathrm{F}$ does not vary with change of fuel grain port diameter or operation time.

- Since burning surface $A_{b u, i}$ is proportional to the length of the fuel grain, this means the thrust increases as the length of the fuel grain raised to the power $1 /(1-n)$, For $\mathrm{n}=0.5$ then $\mathrm{F} \propto \mathrm{L}_{\mathrm{fu}}^{2}$, therefore, high thrust requirements leads to long fuel grains.

During the second phase of the study, the experimental work has lead to the following conclusions:

- Observations of the fuel grain active channels before and after firings reveals that, the remaining fuel port surface is relatively smooth with black carbon traces and slight inflating near the injection head. This is better demonstrated with small initial port (5mm).

- Regression rate of hybrid fuel grain was enhanced by addition of Al powder. Adding up to $7.5 \%$ gives the best performance as regression rate increases by $90 \%$ and chamber pressure increases by $40 \%$ compared to basic configuration $(0 \% \mathrm{Al})$.

- Adding $\mathrm{Al}$ powder to $\mathrm{PE}$ fuel proved to have the following impact on performance

- More smooth fuel grain surface and less soot have been observed when using Al.

- Higher regression rates are more significant at $\mathrm{Al}$ powder additive increased up to $7.5 \%$ by mass.

- Combustion efficiency reaches about $93 \%$ with addition of $2.5 \% \mathrm{Al} \%$.

- Less instability is achieved as compared with pure PE combustion.

- Metal additives lead to decreased nozzle life due to high temperature and erosive effect.

- Reduced emissions of product gases (soot, unburned hydrocarbons).

A throttling capability (maximum to minimum chamber pressure) of (10.7/4.1) could be achieved by the oxidizer flow rate changed by $14.4 \%$ decreases $(10.4$ to $8.9 \mathrm{gm} / \mathrm{sec})$ during experimental work.

\section{7: REFERENCES}

[1] David, A., "Hybrid Rocket Development History," AIAA-No. 91-2515, June 24-26, 1991.

[2] Loh, W.H.T., "Jet, Rocket, Nuclear, Ion, And Electric Propulsion: Theory And Design," New York: Springer-Verlag, 1968.

[3] Lengelle, G., "Hybrid Propulsion, Historical Aspect. Context. International Activities," Energetic Dept., ONERA, France, Jan. 2003

[4] Winfried M.S., and Schmucker, R.H., "Development of A Small Hybrid Rocket Motor," Institute of astronauts, Technical University Munchen, Sep. 1971.

[5] Winfried M.S., and Schmucker, R.H., "Influence of Different Parameters on the Starting Behavior Of Hybrid Engines," Institute of Astronauts, Technical University Munchen, 14 April, 1974.

[6] Tuzinsk, W.A., "Hybrid Rocket," Institute of Astronauts, Technical University Munchen, 14 April 1970.

[7] Gany, A., Timnat, Y.M., and Wolfshtein, M., "Tow-Phase flow Effects on hybrid Combustion," ActaAstronautica, Vol. 3, PP. 241-263, 1976.

[8] Gany, A., and Timnat, Y.T., "Parametric Study Of a Hybrid Rocket Motor," Israel Journal of Technology, Vol. 10, No. 1-2, PP. 85-96, 1972.

[9] Gany, A., "Scale Effects in Hybrid Motor Under Similarity Conditions," AIAA 96-2846, July 1996.

[10] Paul, P.J., Jain, V.K., and Chanda, M., "Studies on the Hybrid Rocket Motor," Proc. Indian Acad. Sci., Vol. C2, part 1, May 1979, PP. 525-533.

[11] Hukunda, H.S., Jain, V.K., and Paul, P.J., "A Review of Hybrid Rockets: Present Status and Future Potential,” Proc. Indian Acad. Sci., Vol. C2, part 1, May 1979, PP. 215-242. 
[12] Lydon, M.C., and Simmons, R.J., "Hybrid Sounding Rocket Development at the United State Force Academy,"

[13] Greiner, B., and Frederick, R.A., "Results of Lab-scale Hybrid Rocket Motor Investigation," AIAA 92-3301, July 1992.

[14] Wolfhard, H.G., Glassman, L., and Leon G., "Heterogeneous Combustion," Technical Papers Based on AIAA, Academic Press, New York, 1964

[15] Sellers, J.J., "Investigation into Low-Cost Propulsion Systems for Small Satellite Missions," Ph.D. Thesis, University of Surrey, June 1996

[16] Brown, R and Seller, J.J., "Practical Experience with Hybrid Peroxide Hybrid Rocket," 1st Hydrogen Peroxide Workshop, Guilford, Surrey, 1998.

[17] Murthy, K.M., and Jain, S.R., "Studies on Some Novel Hypergolic Hybrid Systems," IAF 87-271, October 10-17, Brighton, UK, 1987.

[18] Humble, R., Henry, Gary, N.and Larson, Wiley, J., "Propulsion System Analysis and Design," United States Air Force Academy, 1995.

[19] Sutton, G., "Rocket Propulsion Elements," Sixth Edition, John Wiley, New York, 1992.

[20] Capt. Eng. Meteb K. J. Al-Timimi, "Prediction of Hybrid Rocket Motor Regression Rate"M.Sc thesis, MTC, Cairo, Aug. 2009.

Selph, C., "Computer Program For Calculation of Complex Chemical Equilibrium Composition," NASA SP-273, United States Air Foece Academy, version, July 1994. 